\title{
1,25-Dihydroxycholecalciferol: endocrinology meets the immune system
}

\author{
Evelyne van Etten, Brigitte Decallonne and Chantal Mathieu* \\ Laboratory of Experimental Medicine and Endocrinology, Catholic University of Leuven, Herestraat 49, 3000 Leuven, Belgium
}

\begin{abstract}
Previous work has demonstrated that, besides its effects on $\mathrm{Ca}$ and bone metabolism, the active form of cholecalciferol, 1,25-dihydroxycholecalciferol $\left(1,25(\mathrm{OH})_{2} \mathrm{D}_{3}\right)$, possesses pronounced immunomodulatory effects. In non-obese diabetic (NOD) mice primary (before disease onset), secondary (after insulitis but before diabetes onset) as well as tertiary (after transplantation of syngeneic islets) prevention of diabetes was demonstrated with $1,25(\mathrm{OH})_{2} \mathrm{D}_{3}$ and its chemicallymanufactured non-hypercalcaemic analogues. $1,25(\mathrm{OH})_{2} \mathrm{D}_{3}$ exerts its immune effects both at the level of the T lymphocyte (shift in cytokine profile from T-helper (Th) 1 to Th2, enhanced sensitivity to apoptosis-inducing signals) as well as at the level of the antigen-presenting cell (reduced antigen presentation, reduced production of Th1-promoting cytokines, reduced expression of co-stimulatory molecules). Also, physiologically, $1,25(\mathrm{OH})_{2} \mathrm{D}_{3}$ is believed to have a role in the immune system by serving as a negative feedback signal, limiting the mounted immune reaction. To test the clinical applicability of $1,25(\mathrm{OH})_{2} \mathrm{D}_{3}$ as treatment for type 1 diabetes in genetically-at-risk young children, we tested whether short-term early-life intervention with cholecalciferol or non-hypercalcaemic analogues of $1,25(\mathrm{OH})_{2} \mathrm{D}_{3}$ could prevent diabetes in NOD mice. Significant protection of pancreatic $\beta$ cells against autoimmune destruction was observed in analogue-treated and especially in cholecalciferol-treated NOD mice as compared with controls $(P<0 \cdot 005)$. This short-term early-life intervention was, however, not able to protect the mice from developing diabetes during their lifetime. Possible solutions are longer or combined treatments with other immunomodulators that have synergistic effects with $1,25(\mathrm{OH})_{2} \mathrm{D}_{3}$ and its analogues.
\end{abstract}

1,25-Dihydroxycholecalciferol: Type 1 diabetes: NOD mice

The activated form of vitamin D, 1,25-dihydroxycholecalciferol $\left(1,25(\mathrm{OH})_{2} \mathrm{D}_{3}\right)$ is well known for its effects on $\mathrm{Ca}$ and bone metabolism, but also non-classical effects of the molecule have been described. In vitro, but also in vivo, $1,25(\mathrm{OH})_{2} \mathrm{D}_{3}$ has potent effects on cell proliferation and cell differentiation, in normal cell types as well as in malignant cell types. Receptors for $1,25(\mathrm{OH})_{2} \mathrm{D}_{3}$ have been found in different immune cells such as cells of the monocyte to macrophage lineage, activated $\mathrm{T}$ lymphocytes and $\mathrm{B}$ lymphocytes (Veldman et al. 2000). In vitro, clear effects can be seen, such as the induction of monocyte differentiation and the inhibition of antigen presentation by antigenpresenting cells (such as macrophages and dendritic cells), inhibition of T-cell proliferation and cytokine production, and inhibition of secretion of antibodies by B-cells. These in vitro effects are reflected in vivo by a potential to prevent autoimmune diseases in different experimental models (e.g. autoimmune diabetes in non-obese diabetic (NOD) mice, experimental autoimmune encephalitis, collagen-induced arthritis) and to prolong graft survival (survival of, for example, pancreatic islets, heart, liver, skin grafts; Casteels et al. 1995, Mathieu \& Adorini, 2002).

A major problem with the in vivo use of $1,25(\mathrm{OH})_{2} \mathrm{D}_{3}$ is the fact that the doses needed to see non-classical effects, such as the immune effects, are high and result in severe hypercalcaemia and accelerated bone remodeling. Due to the flexible structure of $1,25(\mathrm{OH})_{2} \mathrm{D}_{3}$, however, chemists have succeeded in synthesising analogues of the molecule, some of which share the mother molecule's effects on the immune system, but not its effects on $\mathrm{Ca}$ or bone metabolism (Bouillon et al. 1995; Verstuyf et al. 2000).

The questions that we and other research groups have tried to answer are: (1) what is the pharmacological potential of $1,25(\mathrm{OH})_{2} \mathrm{D}_{3}$, and more specifically its analogues, in the prevention and treatment of autoimmune diseases and in the prevention of graft rejection; (2) what are the underlying mechanisms of action; (3) does $1,25(\mathrm{OH})_{2} \mathrm{D}_{3}$ have a physiological role in the immune system. 


\section{Primary prevention of type I diabetes by 1,25-dihydroxycholecalciferol and its analogues}

It has been demonstrated that type 1 diabetes can be prevented in NOD mice by $1,25(\mathrm{OH})_{2} \mathrm{D}_{3}$ (Mathieu et al. 1994b). Treatment of NOD mice from weaning until old age not only prevented clinical diabetes, but also the histological lesion, insulitis, became less prevalent (Mathieu et al. 1992). As mentioned earlier, a major problem when using $1,25(\mathrm{OH})_{2} \mathrm{D}_{3}$ in vivo is its effects on $\mathrm{Ca}$ and bone metabolism; protection against diabetes was achieved using doses near the toxic range. Structural analogues of $1,25(\mathrm{OH})_{2} \mathrm{D}_{3}$ with a dissociation between calcaemic and immune effects, obtained in cooperation with the Department of Organische Chemie (University of Ghent, Ghent, Belgium; Professor M. Vandewalle and Professor P. De Clercq), and also analogues developed by pharmaceutical companies (Leo Pharmaceutical Products, Ballerup, Denmark; Hoffman-La Roche Inc., Nutley, NJ, USA; Schering AG, Berlin, Germany), have been used in the diabetes model in the NOD mouse (Mathieu et al. 1995). Some of these substances were able to reduce the incidence of insulitis and diabetes in the NOD mouse, without any effects on $\mathrm{Ca}$ and bone metabolism.

Also, in human subjects prevention of type 1 diabetes would be optimally achieved by primary prevention, i.e. treatment of genetically-at-risk young children. No side effects can be tolerated in early-life treatment of these children and, therefore, attention has been mainly focused on dietary interventions (e.g. avoidance of cow's milk in the first months of life; Kimpimaki et al. 2001). In the EURODIAB study (Dahlquist et al. 1999) a positive correlation between cholecalciferol supplements in early life and protection against diabetes has been demonstrated.

Based on this clinical study and on the positive results obtained with long-term treatment with $1,25(\mathrm{OH})_{2} \mathrm{D}_{3}$ or its analogues in NOD mice, we investigated whether short-term early-life intervention with supplements of cholecalciferol or with non-hypercalcaemic analogues of $1,25(\mathrm{OH})_{2} \mathrm{D}_{3}$ could prevent type 1 diabetes in the NOD mouse. Thus, NOD mice were treated intraperitoneally with cholecalciferol $(25 \mu \mathrm{g} / \mathrm{d})$ or with one of the non-hypercalcaemic analogues of $1,25(\mathrm{OH})_{2} \mathrm{D}_{3}$ TX522 $(30 \mu \mathrm{g} / \mathrm{kg}$ per d) or TX527 $(2 \cdot 5 \mu \mathrm{g} / \mathrm{kg}$ per $\mathrm{d}$; both analogues were originally synthesised by M. Vandewalle and P. De Clercq and later provided by Théramex SA, Monaco), from 3 to $70 \mathrm{~d}$ of age, corresponding to neonatal life and childhood in human subjects, and followed up for diabetes incidence until 30 weeks of age. Vehicle-treated mice served as controls. At diabetes onset or at 30 weeks of age, mice were killed and pancreatic insulin content was measured (Gysemans et al. 2002). To evaluate drug toxicity, serum and bone Ca levels and serum osteocalcin content (as an index of bone turnover) were measured (Mathieu et al. 1995). None of the treatments resulted in long-lasting effects on $\mathrm{Ca}$ or bone metabolism (data not shown). Although none of the treatments protected NOD mice from diabetes development (Table 1), a significant $(P<0 \cdot 005)$ conservation of $\beta$-cell mass (expressed as higher pancreatic insulin levels) was observed for all treatments (Fig. 1). When analysing diabetic and normoglycaemic mice separately this difference remained evident. This preserved pancreatic
Table 1. Effects of short-term early-life interventions with cholecalciferol and its analogues TX522 and TX527 in NOD mice on diabetes incidence

\begin{tabular}{lrrrrr}
\hline & \multicolumn{3}{c}{ Diabetes incidence } \\
\cline { 2 - 3 } & \multicolumn{2}{c}{ Females } & & \multicolumn{2}{c}{ Males } \\
\cline { 2 - 3 } \cline { 5 - 6 } & $n$ & $\%$ & & $n$ & $\%$ \\
\hline Control & $21 / 34$ & 62 & & $19 / 40$ & 53 \\
Cholecalciferol $(25 \mu \mathrm{g} / \mathrm{d})$ & $5 / 13$ & 38 & & $8 / 19$ & 42 \\
TX 522* $(30 \mu \mathrm{g} / \mathrm{kg} \mathrm{per} \mathrm{d)}$ & $9 / 20$ & 45 & & $11 / 32$ & 34 \\
TX 527* $(2 \cdot 5 \mu \mathrm{g} / \mathrm{kg}$ per d) & $9 / 21$ & 43 & & $9 / 21$ & 43 \\
\hline
\end{tabular}

* Originaly synthesised by M. Vandewalle and P. De Clercq, University of Ghent, Ghent, Blegium and later provided by Théramex SA, Monaco.
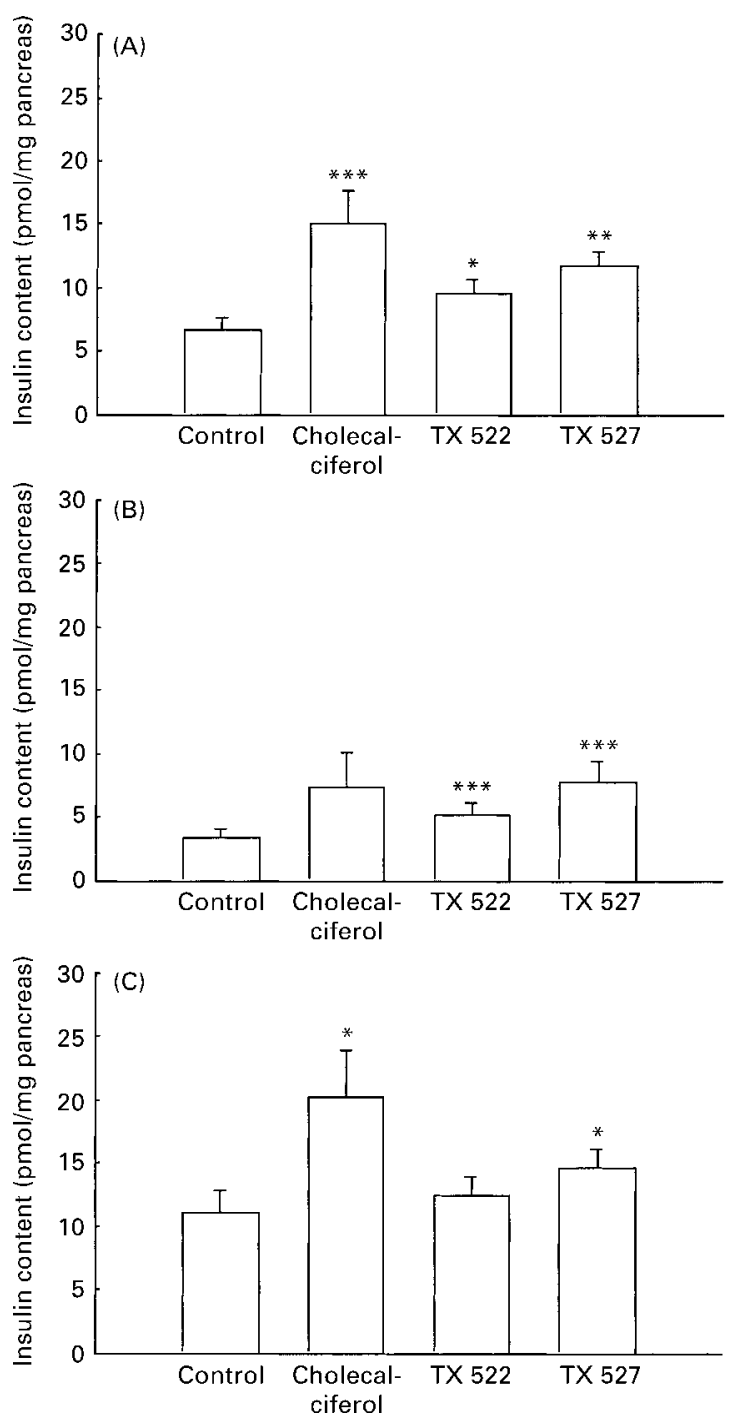

Fig. 1. Pancreas insulin content of $(A)$ all mice, $(B)$ diabetic mice and (C) normoglycaemic mice of the different treatment groups. Mice were treated intraperitoneally with vehicle, cholecalciferol $(25 \mu \mathrm{g} / \mathrm{d})$, TX522 (30 $\mu \mathrm{g} / \mathrm{kg}$ per d) or TX527 $(2.5 \mu \mathrm{g} / \mathrm{kg}$ per d) from 3 to $70 \mathrm{~d}$ of age. At diabetes onset, or at 30 weeks of age, mice were killed and the pancreatic insulin content was measured. Values are expressed as means with their standard errors represented by vertical bars. Mean values were significantly different from those for the control group: ${ }^{*} P<0.05,{ }^{* *} P<0.01,{ }^{* *} P<0.005$. 
insulin content confirms that as well as effects on the immune system, cholecalciferol and its analogues also have direct protective effects on the $\beta$-cells (Hahn et al. 1997; Riachy et al. 2001), making these target cells more resistant to autoimmune-mediated destruction. Unexpectedly, $\beta$-cell protection was most pronounced in mice treated with regular cholecalciferol supplements. This finding could be explained by a defect in the immune stimuli-mediated up-regulation of 25-hydroxycholecalciferol-1 $\alpha$-hydroxylase (the enzyme responsible for the final and rate-limiting step in the synthesis of the active form of cholecalciferol, $\left.1,25(\mathrm{OH})_{2} \mathrm{D}_{3}\right)$ in the macrophages of NOD mice (Overbergh et al. 2000a). This defect might be responsible for inappropriately low levels of $1,25(\mathrm{OH})_{2} \mathrm{D}_{3}$ locally at inflammatory sites, and might be corrected by cholecalciferol supplements. Presently, we are investigating whether defects in macrophage 25-hydroxycholecalciferol- $1 \alpha$-hydroxylase levels are also present in human subjects with type 1 diabetes.

This study indicates that, in contrast to previous results for NOD mice treated for a long period of time with $1,25(\mathrm{OH})_{2} \mathrm{D}_{3}$ or its analogues, treating NOD mice for a short period of time early in life with an analogue of $1,25(\mathrm{OH})_{2} \mathrm{D}_{3}$ is not sufficient to prevent diabetes. Longer or combined treatments with other immunomodulators remain necessary for primary prevention in NOD mice.

\section{Mechanisms of protection from type 1 diabetes by 1,25-dihydroxycholecalciferol and its analogues}

Investigating the mechanisms of protection, we discovered that the well-known defect in suppressor cell function in NOD mice was normalised by treatment with $1,25(\mathrm{OH})_{2} \mathrm{D}_{3}$ or its analogues (Mathieu et al. 1995). In subsequent studies involving cyclophosphamide-induced diabetes we were able to demonstrate again that these suppressor cells were clearly present after $70 \mathrm{~d}$ of therapy in $1,25(\mathrm{OH})_{2} \mathrm{D}_{3}$ - or analoguetreated NOD mice (Casteels et al. 1998b). Nevertheless, in the latter studies it was shown that these suppressor cells were not indispensable for the protective effect of $1,25(\mathrm{OH})_{2} \mathrm{D}_{3}$ and its analogues. Analysing the cytokine profile locally in these pancreases, we found a clear shift from T-helper (Th)1 to Th2 expression patterns in $1,25(\mathrm{OH})_{2} \mathrm{D}_{3}$-treated mice. These observations and the fact that protection continued after withdrawal of the treatment, suggested that $1,25(\mathrm{OH})_{2} \mathrm{D}_{3}$ treatment had resulted in the induction of tolerance for $\beta$-cells, possibly by elimination of autoimmune effector (Th1) cells that otherwise would have caused diabetes. In the following studies we were able to demonstrate that treatment with $1,25(\mathrm{OH})_{2} \mathrm{D}_{3}$ caused a restoration of the impaired apoptosis sensitivity in NOD thymocytes and splenocytes, both in female and male mice (Casteels et al. 1998c). At present we are investigating the molecular signals involved in the apoptosis resistance in NOD lymphocytes and the way in which $1,25(\mathrm{OH})_{2} \mathrm{D}_{3}$ influences these signals.

Although it is well known that $1,25(\mathrm{OH})_{2} \mathrm{D}_{3}$ directly affects $\mathrm{T}$ lymphocytes in vitro as well as in vivo (as shown in NOD mice by the generation of suppressor cells and improved elimination of autoreactive effector cells), it is believed that the effects of $1,25(\mathrm{OH})_{2} \mathrm{D}_{3}$ are primarily mediated through its action on antigen-presenting cells, of which dendritic cells (DC) are the most potent. In a study using in vitro-generated human $\mathrm{DC}$, we showed that treatment with the non-hypercalcaemic $1,25(\mathrm{OH})_{2} \mathrm{D}_{3}$ analogue TX 527 has a major impact on the differentiation and maturation, as well as function, of these monocytederived DC (Van Halteren et al. 2002). With TX 527 treatment during DC maturation, a shift was induced from a Th1-promoting phenotype towards a Th2-promoting phenotype. These results confirm the in vitro effects of $1,25(\mathrm{OH})_{2} \mathrm{D}_{3}$ itself on human DC (Penna \& Adorini, 2000). Subsequent stimulation of an autoreactive T-cell clone resulted in a profound redirection of its cytokine profile (lower levels of Th1 cytokines), suggesting a mechanism of action by which the secondary and tertiary prevention of diabetes in the NOD mouse by $1,25(\mathrm{OH})_{2} \mathrm{D}_{3}$ could be explained. In this context, we are now investigating the effects of $1,25(\mathrm{OH})_{2} \mathrm{D}_{3}$ treatment on in vitro and in vivo $\mathrm{DC}$ development of NOD mice.

On the other hand, when treatment was initiated during monocyte differentiation, a totally different cell type was generated, lacking the DC-specific surface markers and morphology. It is known that monocytes may be considered as relatively immature precursors with multiple differentiation potential, depending on the micro-environment. Cytokines and inflammatory substances play an important role in the final decision, determining whether monocytes will acquire DC, macrophage, osteoclastic or other characteristics and functions (Chomarat et al. 2000). Currently, we are analysing further the phenotype and function of the cell type generated by continuous treatment with $1,25(\mathrm{OH})_{2} \mathrm{D}_{3}$ or its analogues.

\section{Secondary prevention of type I diabetes by analogues of 1,25-dihydroxycholecalciferol}

We have shown that treatment with analogues of $1,25(\mathrm{OH})_{2} \mathrm{D}_{3}$ can lead to secondary prevention, i.e. prevention of the progression of an initiated $\beta$-cell attack (reflected by the presence of insulitis) to clinical disease, diabetes (Casteels et al. 1998a). Some analogues of $1,25(\mathrm{OH})_{2} \mathrm{D}_{3}$ were very effective in preventing this progression from insulitis (demonstrated in each individual mouse in pancreatic biopsies taken at the age of $70 \mathrm{~d}$, before starting therapy) to overt diabetes, even when given alone. In combination with a short induction treatment of 3 weeks with the classical immunosuppressant, cyclosporin $\mathrm{A}$, the efficacy of the analogues in blocking disease progression was further increased. Again, because of the very short period of treatment with cyclosporin A, no long-term immunosuppression was detected. Interestingly, in this model of secondary prevention no suppressor cells could be demonstrated in co-transfer experiments. Within the pancreases of protected mice, we again noted a shift from Th1-type cytokines towards Th2-type cytokines by measuring cytokine mRNA production locally in the islets. In further experiments we have been able to demonstrate that this shift from a Th1 cytokine profile to a Th2 cytokine profile mediated by $1,25(\mathrm{OH})_{2} \mathrm{D}_{3}$ or its analogues only happens for autoantigens, but not 'diabetes-irrelevant' antigens (Overbergh et al. 2000b). 


\section{Tertiary prevention of type I diabetes}

Islet transplantation is a potential cure for patients with type 1 diabetes. Compared with patients that have become insulin dependent due to pancreatic surgery, patients with type 1 diabetes destroy the newly-transplanted islets more vigorously, thus creating the need for heavy immunosuppressive regimens (Mathieu, 2000). A cause for this more vigorous reaction is most probably the recurrence of the autoimmune disease itself. In recent years we have focused specifically on this phenomenon of autoimmune recurrence.

We have tested analogues of $1,25(\mathrm{OH})_{2} \mathrm{D}_{3}$ in a model of pure recurrence of autoimmunity, after syngeneic (NOD to NOD) islet transplantation. When neonatal NOD islets were transplanted into spontaneously-diabetic NOD mice, a rapid and specific destruction of the transplanted $\beta$-cells was always found. In this model again therapy with analogues of $1,25(\mathrm{OH})_{2} \mathrm{D}_{3}$ alone was as efficient as cyclosporin $\mathrm{A}$ in prolonging graft survival. Moreover, a combination of analogues of $1,25(\mathrm{OH})_{2} \mathrm{D}_{3}$ and low doses of cyclosporin $\mathrm{A}$ not only synergistically prolonged graft survival, but also allowed the withdrawal of all drugs after 2 months without subsequent recurrence of the disease (Mathieu et al. 1997; Casteels et al. 1998d). This observation suggests that even in the case of tertiary prevention, autoimmune recurrence can be overcome, and thus re-induction of self-tolerance can be achieved. Analysis of the cytokine profile in the grafts themselves again demonstrated the induction of an immune shift from a Th1 profile towards a Th2 profile in mice receiving the combination treatment. In the meantime, we have screened other immunosuppressants for their capacity to act synergistically with analogues of $1,25(\mathrm{OH})_{2} \mathrm{D}_{3}$ and found several good candidates (Mathieu et al. 1994a; Branisteanu et al. 1997; van Etten et al. 2000; Gysemans et al. 2002).

In view of the potential of the xenotransplantation technique as a solution for the human organ shortage which will be encountered should islet replacement become used as a widespread therapy for type 1 diabetes, we studied xenogeneic islet transplantation (rat islets) in NOD mice. We have discovered that after transplantation of xenogeneic islets, an important proportion of these grafts never functions, even under technically controlled circumstances. This phenomenon is known as primary non-function or early graft failure. We demonstrated that this graft failure is far more frequent in autoimmune NOD mice than in nonautoimmune NOD mice or other non-autoimmune-prone mouse strains, and is characterised by high interleukin 1 and low transforming growth factor $\beta$ levels locally in the grafts, as measured by reverse transcription-polymerase chain reaction (Gysemans et al. 2000). Furthermore, we found that analogues of $1,25(\mathrm{OH})_{2} \mathrm{D}_{3}$ or of the classical immunosuppressant leflunomide, both in combination with cyclosporin A, could prevent this primary non-function (Gysemans et al. 2001a,b).

\section{1,25-Dihydroxycholecalciferol as a physiological immunoregulator}

A final part of our work focused on the analysis of the physiological role of $1,25(\mathrm{OH})_{2} \mathrm{D}_{3}$ in the immune system.
Receptors for $1,25(\mathrm{OH})_{2} \mathrm{D}_{3}$ have been described in many cells of the immune system (Veldman et al. 2000), and indirect evidence has existed for many years to suggest that cells of the immune system can produce $1,25(\mathrm{OH})_{2} \mathrm{D}_{3}$. We were the first to demonstrate at the molecular level that the enzyme responsible for the final hydroxylation and activation of vitamin D, 25-hydroxycholecalciferol-1 $\alpha$ hydroxylase, is present in macrophages and originates from the same gene as the enzyme in the kidney, typically involved in $\mathrm{Ca}$ homeostasis (Overbergh et al. 2000a). However, the macrophage gene is regulated in a completely different manner, with immune signals in particular influencing the transcription, while the typical $\mathrm{Ca}$ signals have no effect. On the basis of these findings and the data available on the effects of $1,25(\mathrm{OH})_{2} \mathrm{D}_{3}$ on different cells in the immune system and their cytokine production, we have proposed a physiological role for $1,25(\mathrm{OH})_{2} \mathrm{D}_{3}$ as a negative feedback signal in the activated immune system (Fig. 2). Moreover, we found that NOD mice have a defective upregulation of their macrophage 25-hydroxycholecalciferol$1 \alpha$-hydroxylase in response to immune stimuli, another possible factor contributing to their autoimmunity-prone

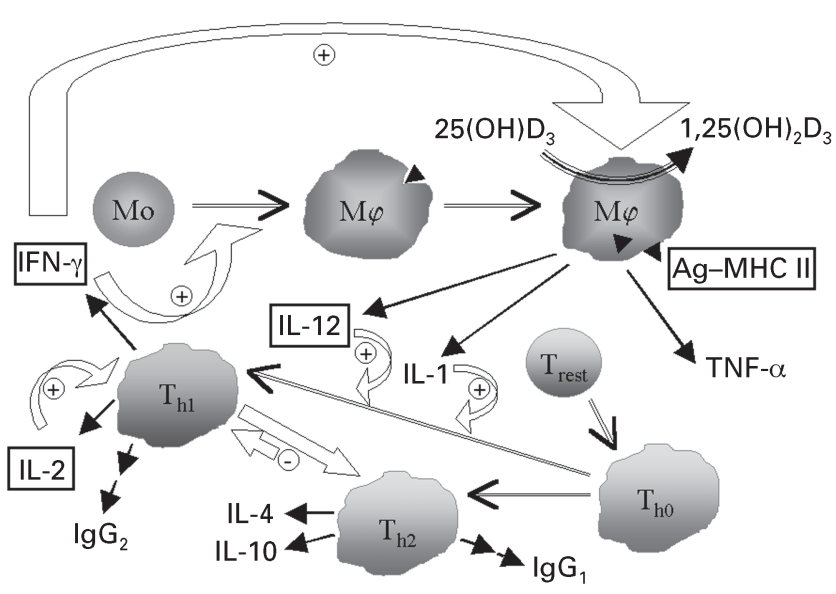

Fig. 1. Physiological role of 1,25-dihydroxycholecalciferol $\left(1,25(\mathrm{OH})_{2} \mathrm{D}_{3}\right)$ in the immune system. On stimulation of macrophages $(\mathrm{M} \phi)$, generally the first cells of the immune system to encounter foreign antigens (e.g. bacteria or graft antigens (Ag)), chemotactic and immuno-stimulating substances (e.g. interleukin (IL) 1, tumour necrosis factor $\alpha$ (TNF- $\alpha)$ and IL-12) are secreted for recruitment and activation of the rest of the immune system, in which $T$ lymphocytes play a central role and move to the site of inflammation in great numbers. These $\mathrm{T}$ lymphocytes will, in a positive feedback loop, further stimulate $M \phi$ by secretion of interferon $\gamma($ IFN- $\gamma)$. After this initial immune activation phase, leading to propagation of the inflammatory reaction, a down-regulation phase is necessary for limitation of the immune response. We propose that one of the down-regulating signals secreted by $\mathrm{M} \phi$ might be $1,25(\mathrm{OH})_{2} \mathrm{D}_{3}$. ( $\square$ ) The cytokines (IL-12, IL-2, IFN- $\gamma$ ) and surface molecules (major histocompatibility complex (MHC) class-II) that are down regulated by $1,25(\mathrm{OH})_{2} \mathrm{D}_{3}$. A defect in $1,25(\mathrm{OH})_{2} \mathrm{D}_{3}$ secretion by $M \phi$ might be a contributing factor to pathological deviations of the immune system, such as autoimmunity. $25(\mathrm{OH}) \mathrm{D}_{3}$, 25-hydroxycholecalciferol; Mo, monocytes; $\mathrm{T}_{\mathrm{h} 1}, \mathrm{~T}_{\mathrm{h} 2}, \mathrm{~T}_{\mathrm{h} 0}$, T-helper 1, 2, 0 respectively; $\mathrm{T}_{\text {rest }}$, other $\mathrm{T}$ lympocytes; $\mathrm{Ag}$, foreign antigen (e.g. bacteria or graft antigen); +, - , positive and negative feedback respectively; Ig, immunoglobulin. 
immune system. With analysis of the 25-hydroxycholecalciferol- $1 \alpha$-hydroxylase promotor using transfection experiments we are currently further addressing this issue.

\section{Conclusions}

Our work has demonstrated a clear pharmacological potential for $1,25(\mathrm{OH})_{2} \mathrm{D}_{3}$, particularly its structural analogues with less calcaemic effects, as tools in the prevention and treatment of autoimmune diseases. This effect is based on shifts in cytokine profile (from Th1 to Th2), that occur specifically for the autoantigens, and on enhanced sensitivity of the autoreactive T lymphocytes to apoptotic signals, thus leading to improved elimination of these potentially-dangerous cells. These effects of $1,25(\mathrm{OH})_{2} \mathrm{D}_{3}$ are primarily mediated via its actions at the level of the antigen-presenting cell (with altered phenotype and cytokine production), although direct effects at the T-cell level are also present.

$1,25(\mathrm{OH})_{2} \mathrm{D}_{3}$ or its analogues can therefore be considered in interventions aimed at the prevention or treatment (islet transplantation) of human type 1 diabetes.

\section{References}

Bouillon R, Verstuyf AM, Verlinden L, Branisteanu D, Mathieu C \& Van Baelen H (1995) Non-hypercalcemic pharmacological aspects of vitamin D analogs. Biochemical Pharmacology 50, 577-583.

Branisteanu D, Mathieu C \& Bouillon R (1997) Synergism between sirolimus and 1,25-dihydroxyvitamin $\mathrm{D}_{3}$ in vitro and in vivo. Journal of Neuroimmunology 79, 138-147.

Casteels K, Bouillon R, Waer M \& Mathieu C (1995) Immunomodulatory effects of $1,25(\mathrm{OH})_{2} \mathrm{D}_{3}$. Current Opinion in Nephrology and Hypertension 4, 313-318.

Casteels K, Bouillon R, Waer M, Valckx D, Overbergh L, Laureys J \& Mathieu C (1998a) Prevention of type I diabetes by late intervention with non-hypercalcemic analogues of vitamin $\mathrm{D}_{3}$ in combination with cyclosporin A. Endocrinology 139, 95-102.

Casteels K, Waer M, Bouillon R, Depovere J, Valckx D, Laureys J \& Mathieu C (1998b) 1,25-Dihydroxyvitamin $\mathrm{D}_{3}$ restores sensitivity to cyclophosphamide-induced apoptosis in NOD mice and protects against diabetes. Clinical and Experimental Immunology 112, 181-187.

Casteels K, Waer M, Laureys J, Depovere J, Gysemans C, Bouillon $\mathrm{R}$ \& Mathieu C (1998c) Sex difference in resistance to dexamethasone-induced apoptosis in NOD mice: treatment with $1,25(\mathrm{OH})_{2} \mathrm{D}_{3}$ restores defect. Diabetes 47, 1033-1037.

Casteels K, Waer M, Laureys J, Valckx D, Depovere J, Bouillon R \& Mathieu C (1998d) Prevention of autoimmune destruction of syngeneic islet grafts in spontaneously diabetic NOD mice by a combination of a vitamin $\mathrm{D}_{3}$ analogue and cyclosporin A. Transplantation 65, 1-8.

Chomarat P, Banchereau J, Davoust J \& Packula AK (2000) IL-6 switches the differentiation of monocytes from dendritic cells to macrophages. Nature Immunology 1, 510-514.

Dahlquist GG, Patterson C \& Soltesz G (1999) Vitamin D supplement in early childhood and risk for type 1 (insulindependent) diabetes mellitus. The EURODIAB Substudy 2 Study Group. Diabetologia 42, 51-54.

Gysemans C, van Etten E, Overbergh L, Verstuyf A, Waer M, Bouillon R \& Mathieu C (2002) Treatment of autoimmune diabetes recurrence in non-obese diabetic mice by mouse interferon- $\beta$ in combination with an analogue of $1 \alpha, 25$ - dihydroxyvitamin- $\mathrm{D}_{3}$. Clinical and Experimental Immunology 128, 213-220.

Gysemans C, Waer M, Bouillon R \& Mathieu C (2001a) A combination of KH1060, a vitamin D3 analogue and cyclosporin prevents early graft failure and prolongs graft survival of xenogeneic islets in non obese diabetic mice. Transplantation Proceedings 33, 2365.

Gysemans C, Waer M, Bouillon R \& Mathieu C (2001b) Leflunomide and its analogue X920715 synergize with cyclosporin A in preventing early graft failure and delaying graft rejection of xenogeneic islets in non-obese-diabetic mice. Transplantation Proceedings 33, 2094-2095.

Gysemans CA, Waer M, Valckx D, Laureys J, Mikhalsky D, Bouillon R \& Mathieu C (2000) Early graft failure of xenogeneic islets in NOD mice is accompanied by high levels of interleukin1 and low levels of transforming growth factor- $\beta$ mRNA in the grafts. Diabetes 49, 1992-1997.

Hahn HJ, Kuttler B, Mathieu C \& Bouillon R (1997) 1,25dihydroxyvitamin $\mathrm{D}_{3}$ reduces $\mathrm{MHC}$ antigen expression on pancreatic beta-cells in vitro. Transplantation Proceedings 29, 2156-2157.

Kimpimaki T, Erkkola M, Korhonen S, Kupila A, Virtanen SM, Ilonen J, Simell O \& Knip M (2001) Short-term exclusive breast-feeding predisposes young children with increased genetic risk of Type 1 diabetes to progressive beta-cell autoimmunity. Diabetologia 44, 63-69.

Mathieu C (2000) Current limitations of islet transplantation. Transplantation Proceedings 33, 1707-1708.

Mathieu C \& Adorini L (2002) The coming of age of 1,25dihydroxyvitamin $\mathrm{D}_{3}$ analogs as immunomodulatory agents. Trends in Molecular Medicine 8, 174-179.

Mathieu C, Bouillon R, Rutgeerts O, Vandeputte M \& Waer M $(1994 a)$ The activated form of vitamin $\mathrm{D}\left[1,25(\mathrm{OH})_{2} \mathrm{D}_{3}\right]$ and its analogues as dose reducing agents for cyclosporin and FK506 in vitro and in vivo. Transplantation Proceedings 26, 3048-3049.

Mathieu C, Casteels K, Waer M, Laureys J, Valckx D \& Bouillon $R$ (1997) Prevention of diabetes recurrence after islet transplantation in NOD mice by analogues of $1,25(\mathrm{OH})_{2} \mathrm{D}_{3}$ in combination with CyA. Transplantation Proceedings 28, 3095.

Mathieu C, Laureys J, Sobis H, Vandeputte M, Waer M \& Bouillon R (1992) 1,25-Dihydroxyvitamin $\mathrm{D}_{3}$ prevents insulitis in NOD mice. Diabetes 41, 1491-1495.

Mathieu C, Waer M, Casteels K, Laureys J \& Bouillon R (1995) Prevention of type 1 diabetes in NOD mice by non-hypercalcemic doses of a new structural analogue of $1,25(\mathrm{OH})_{2} \mathrm{D}_{3}$, KH1060. Endocrinology 136, 866-872.

Mathieu C, Waer M, Laureys J, Rutgeerts O \& Bouillon R (1994b) Prevention of type I diabetes in NOD mice by 1,25-dihydroxyvitamin $\mathrm{D}_{3}$. Diabetologia 37, 552-558.

Overbergh L, Decallonne B, Valckx D, Verstuyf A, Depovere J, Laureys L, Rutgeerts O, Saint-Arnaud R, Bouillon R \& Mathieu $\mathrm{C}$ (2000a) Identification and immune regulation of 25-hydroxyvitamin D-1-alpha-hydroxylase in murine macrophages. Clinical and Experimental Immunology 120, 139-146.

Overbergh L, Decallonne B, Waer M, Rutgeerts O, Valckx D, Casteels K, Laureys J, Bouillon R \& Mathieu C (2000b) 1,25Dihydroxyvitamin D3 induces an autoantigen specific Th1/Th2 immune shift in nonobese diabetic mice immunized with GAD65 (p524-543). Diabetes 49, 1301-1307.

Penna G \& Adorini L (2000) 1 $\alpha, 25$-dihydroxyvitamin $\mathrm{D}_{3}$ inhibits differentiation, maturation, activation and survival of dendritic cells leading to impaired alloreactive $\mathrm{T}$ cell activation. Journal of Immunology 164, 2405-2411.

Riachy R, Vandewalle B, Belaich S, Kerr-Conte J, Gmyr V, Zerimech F, d'Herbomez M, Lefebvre J \& Patou F (2001) Beneficial effect of 1,25-dihydroxyvitamin $\mathrm{D}_{3}$ on cytokine- 
treated human pancreatic islets. Journal of Endocrinology 169, 161-169.

van Etten E, Branisteanu D, Verstuyf A, Waer M, Bouillon R \& Mathieu C (2000) Analogs of 1,25-dihydroxyvitamin D3 as dose reducing agents for classical immunosuppressants. Transplantation 69, 1932-1942.

Van Halteren AG, van Etten E, de Jongh EC, Bouillon R, Roep BO \& Mathieu C (2002) Redirection of human autoreactive T cells upon interaction with dendritic cells modulated by TX527, an analogue of 1,25-dihydroxyvitamin $\mathrm{D}_{3}$. Diabetes (In the Press).

Veldman CM, Cantorna MT \& DeLuca HF (2000) Expression of 1,25-dihydroxyvitamin $\mathrm{D}(3)$ receptor in the immune system. Archives of Biochemistry and Biophysics 374, 334-338.

Verstuyf A, Segaert S, Verlinden L, Bouillon R \& Mathieu C (2000) Recent developments in the use of vitamin D analogues. Expert Opinion on Investigational Drugs 9, 443-455. 